\title{
Serpentine leafminer (Liriomyza trifolii) on potato (Solanum tuberosum): field observations and plant photosynthetic responses to injury
}

\author{
Mosca-minadora (Liriomyza trifolii) na cultura da batata (Solanum tuberosum): observações de \\ campo e respostas fotossintéticas da planta à injúria
}

\author{
Adeney de Freitas Bueno ${ }^{\mathrm{I}}$ Benjamin Zechmann ${ }^{\text {II }}$ William Wyatt Hoback ${ }^{\text {II }}$ \\ Regiane Cristina Oliveira de Freitas Bueno ${ }^{\mathrm{III}}$ Odair Aparecido Fernandes ${ }^{\text {IV }}$
}

\section{ABSTRACT}

Serpentine leafminers, Liriomyza spp. (Diptera: Agromyzidae), are polyphagous insects that feed on numerous crops worldwide including potato. Recently, leafminer larvae (Liriomyza trifolii) have become an economically important pest of potato. The larvae eat the mesophyll of leaflets leaving long winding tunnels inside the leaflets. The photosynthetic effects of larval tunneling on the remaining leaf tissue are unknown. In 2003, physiological responses of potato to leafminer, L. trifolii were evaluated in Kearney, Nebraska, USA The leaflets were examined 7 and 14 days post infestation for leaf area injury, photosynthetic rates and fluorescence. Leafminers caused up to $13 \%$ leaf area loss due to leafminer injury with no effect on the photosynthetic rates of the remaining leaf tissue thus having similar effects as other gross tissue removers. However, fluorescence measures revealed changes in the photosynthetic efficiency and depend of the type of injury, it may lead to early leaf senescence. Field monitoring of $\boldsymbol{L}$. trifolii infestations showed that treatments with abamectin were effective in reducing leafminer numbers and had no immediate effect on beneficial parasitoid from Eulophidae family suggesting that abamectin is a good option for chemical control.

Key words: plant-insect interaction, chemical control, photosynthesis

RESUMO

Moscas-minadoras, Liriomyza spp. (Diptera: Agromyzidae), são pragas polífagas distribuídas por todo o mundo, que se alimentam de diferentes culturas, incluindo a

\begin{abstract}
da batata. Recentemente, a mosca-minadora (Liriomyza trifolii) tem tornado-se uma praga importante na cultura da batata. As larvas comem o mesófilo foliar, deixando longas minas no interior das folhas. O efeito na fotossíntese do tecido foliar remanescente das minas é desconhecido. Em 2003, as respostas fisiológicas das plantas de batata à mosca-minadora L. trifolii foram avaliadas no condato de Kearney, Nebraska, EUA. As avaliações de área foliar danificada, fotossíntese e fluorescência foram feitas aos 7 e 14 dias após a infestação. A moscasminadoras causaram até $13 \%$ de área foliar danificada, com nenhuma redução na capacidade fotossintética da área remanescente dos folíolos, tendo, portanto, efeitos semelhantes aos do grupo dos insetos desfolhadores. Entretanto, os resultados de fluorescência revelaram mudanças na eficiência fotossintética e, dependendo do tipo de injúria, esta pode levar a uma senescência precoce da folha. Monitoramentos de campo mostraram que o abamectin é eficiente no controle da moscaminadora, L. trifolii, com um baixo impacto aos parasitóides da família Eulophidae, podendo ser uma boa opção de controle químico.
\end{abstract}

Palavras-chave: interação inseto-planta, controle químico, fotossíntese.

\section{INTRODUCTION}

Serpentine leafminers, Liriomyza spp. (Diptera: Agromyzidae), are polyphagous worldwide insects that feed on various crops including potato

\footnotetext{
IDepartamento de Biologia, Universidade de São Paulo (USP), 14040-901, Ribeirão Preto, SP, Brasil. Endereço para correspondência: Condomínio Monte Verde Casa, 156. Rua Dona Firmina s/n, Setor Sítio Recreio dos Ipês, 74681-450, Goiânia, GO, Brasil. E-mail: adeney@cnpso.embrapa.br.

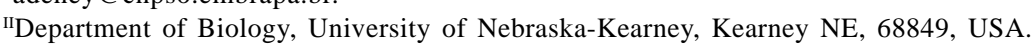

IIIDepartamento de Entomologia, Fitopatologia e Zoologia Agrícola, Universidade de São Paulo (ESALQ/USP), Piracicaba, SP, 13418-900, Brasil.

${ }^{\mathrm{IV}}$ Departamento de Fitossanidade, UNESP, Jaboticabal, SP, Brasil.
} 
(PARRELLA, 1987). Among the host plants, Solanaceae is one of the most important families (SOUZA, 1993). On potato (Solanum tuberosum), serpentine leafminers were of secondary importance; however, biological control agents have been reduced by pesticides applied on potato fields, leading to leafminer outbreaks of economic importance (EWELL et al., 1990). In Nebraska, USA, L. trifolii outbreaks have occurred late in the season during 2003-2005. High levels of infestation (more than $70 \%$ of potato leaflets infested with at least one leaf miner) have occurred and growers have attempted chemical control. In Brazil, leafminers have also being a serious problem for potato growers (SOUZA \& REIS, 1999). Therefore, studies to assess plant-leafminer interactions in potato and other crops are needed in order to improve economic agricultural decision to be made in both North and South America.

The capacity of leafminers to reduce yield has been documented for several crops (SPENCER, 1973; HILJE et al., 1993). The injury is primarily caused by the larvae because they start to feed immediately after eclosion and feed constantly until pupation outside the leaf (PARRELLA, 1987; SOUZA \& REIS, 1999). Liriomyza spp. injury is known to reduce photosynthetic capacity for Chrysanthemum, celery (Alpium graveolens), tomato (Lycopersicon esculentum), and lima beans (Phaseolus lunatus) (JOHNSON et al., 1983; PARRELLA et al., 1985; TRUMBLE et al., 1985; MARTENS \& TRUMBLE, 1987). At present, however, the relationship between L. trifolii mining injury and their effects on potato leaflet photosynthesis has not been tested.

Better knowledge of the plant's physiological capacity to withstand insect injury and the effect of pesticides on a pest and its natural enemies is necessary before establishing accurate density treatment levels for any crop system (HIGLEY, 2001). It is unclear if the tunneling caused by leafminer larval feeding changes the photosynthetic response of the remaining leaf tissue of potato. If there are no changes in photosynthetic response in the remaining leaf tissue then the injury caused by leafminer feeding could be characterized as simple defoliation. Further if leafminer injury can be called defoliation then economic injury levels developed for other defoliating insects could also be utilized in the management of this pest.

Therefore, the objectives of this study were: 1) to examine if the injury caused by $\mathbf{L}$. trifolii would cause differences in photosynthesis and chlorophyll fluorescence parameters on the remaining tissue and 2) to examine the effects of abamectin pesticide on $\boldsymbol{L}$. trifolii and its natural enemies, in particular, parasitoids from the family Eulophidae.

\section{MATERIAL AND METHODS}

Leafminers: pupae of Liriomyza trifolii were obtained from a colony maintained at the University of California, Riverside, California, USA. The pupae that were close to adult emergence were used to infest the experimental plants.

Field experiment: during August, 2003, two field experiments were conducted in a commercial potato field in Kearney County in south-central Nebraska, USA using a Frito Lay proprietary chipping variety. Potatoes were planted spaced 0.9 meter between rows having 4 plants/linear meter in each row. In August, potatoes were in the bulking stage (after blooming). Both experiments were conducted using a randomized complete block design, with 8 replicates. The treatments were a factorial of 2 ( 7 and 14 days after infestation) $\mathrm{x} 3$ (uncaged control leaflet, caged control leaflet, and infested leaflets) for photosynthetic capacity. Fluorescence measurements were made using a factorial of 2 ( 7 and 14 days after infestation) x 2 (caged control leaflet and infested leaflet).

Experimental plants were infested with 10 pupae of $\boldsymbol{L}$. trifolii per leaflet by placing pupae in finemeshed leaf cages. Leafminer injury and control treatments were imposed on the top central leaflet located on the upper $4^{\text {th }}$ node. Caged control treatment (non-infested leaflets) was treated similarly. Seven or 14 days after infestation, cages were removed, photosynthesis and fluorescence readings were taken (see below) and injury was evaluated.

Photosynthetic rates (A) and chlorophyll parameters were measured from the same leaflets. All readings were taken on remaining uninjured tissue. The measurements were made using a portable photosynthesis system (model LI-6400, Li-Cor, Lincoln, $\mathrm{NE}$ ), with $\mathrm{CO}_{2}$ injector and light source, which allows stable $\mathrm{CO}_{2}$ concentration and light intensity during all measurements. The settings used were: blue light source at $1500 \mathrm{mmol} \mathrm{m}^{-2} \mathrm{~s}^{-1}$ photosynthetic photon flux density (PPFD), $\mathrm{CO}_{2}$ concentration at $400 \mathrm{mmol} \mathrm{CO}_{2} \mathrm{~m}^{-2}$ $\mathrm{s}^{-1}$ and the relative humidity inside the chamber was kept between 45-55\%. Photosynthetic rates were measured on $6 \mathrm{~cm}^{2}$ of leaf area, the maximum area measured by LI-6400. After the photosynthetic measurements, the leaflets were dark-adapted for 20 minutes by using dark leaf clips in order to measure the chlorophyll fluorescence parameters (Fv/Fm, qN, qP and ETR) using a leaf chamber fluorometer (Model Licor-6400-40, Li-Cor, Lincoln, NE). After the 20 minutes of dark adaptation, the leaves were exposed to the weak, modulated beam for determination of $F_{0}$. A pulse of saturated light (150 PAR for 30 seconds) was imposed 
to obtain $\mathrm{F}_{\mathrm{m}}$. This allows determination of $\mathrm{F}_{\mathrm{v}} / \mathrm{F}_{\mathrm{m}}$ of dark adapted leaves. The leaves were then exposed to actinic light (1350 PAR) and saturating pulses of light were imposed in order to obtain the quenching analysis (qP and $\mathrm{qN}$ ) at steady-state fluorescence. Dark adaptation was used to get fluorescence data from leaves with cleared plastoquinone pools. Then the instrument was able to collect fluorescence data while the photosynthesis apparatus was collecting light and converting the light into usable ATP and NADPH. Mean weather conditions inside trial area during the experimental period was temperature of $24.1^{\circ} \mathrm{C}$ (maximum and minimum temperatures reached $32.7^{\circ} \mathrm{C}$ and $17.4^{\circ} \mathrm{C}$, respectively), a relative humidity varying from 41 to $73 \%$ and a total precipitation of $8.38 \mathrm{~mm}$ plus irrigation accordingly to the farm irrigation schedule and needs.

After all the measurements were taken the potato leaflets were collected and photographed. The leaflet images were digitized, and the percent of leaf mined by $\mathbf{L}$. trifolii was determined using image analysis software (Mocha, Jandel Scientific, San Rafael, CA).

Field observations and insecticide efficacy: a second potato field under commercial production located approximately $11 \mathrm{~km}$ north of Minden, Kearney County, Nebraska had high populations of $\boldsymbol{L}$. trifolii present on July 1, 2003. Field scouting revealed that the greatest concentration of leafminers was present in the southwest (SW) quadrant of the field, so observations were initially confined to this quadrant. Observations consisted of pulling 40 leaves from the $4^{\text {th }}$ node of random plants within the study area approximately every other day beginning on July 2, 2003. The leaves were examined in the laboratory and the number of live larvae in the tunnels and number of parasitized larvae were determined. On 20/July/2003, $80 \%$ of leaflets contained at least one leafminer and the farmer decided that treatment was necessary. In addition to the initial observation area, leafminers had spread to other areas of the field and premature leaf drop was observed in areas of the SW quadrant of the field, even though, damage was inflicted after bloom when potato plants are less susceptible to defoliation, more than one month remained prior to harvest. Although the decision to manage the leafminer population was made by the farmer, no pesticide information for leafminer in potato was available. Thus the farm applied different rates of insecticide to the SW and southeast (SE) quadrants of the field while leaving the north half $(\mathrm{N})$ of the field as an untreated control or check strip. Abamectin (Agrimek, Syngenta) was chosen based on its effectiveness on another leafminer, Liriomyza huidobrensis. Treatments were made on July 21 and August 4, 2003, at different rates for each treatment area. The SW quadrant of the field received $583 \mathrm{~mL} \mathrm{ha}^{-1}$ of abamectin and the SE quadrant received $1166 \mathrm{~mL} \mathrm{ha}^{-1}$. All field observations were continued until August 13, 2003.

Data Analysis: photosynthetic and fluorescence data were analyzed using PROC MIXED procedure of the SAS program (SAS INSTITUTE, 2001). Means were separated by Stundet t-test $(\mathrm{P}=0.05)$.

\section{RESULTS AND DISCUSSION}

Leafminer mining produced mean injury $( \pm$ SE) of $8.37 \pm 1.78 \%$ on day 7 after infestation and $12.38 \pm 1.78 \%$ on day 14 after infestation. Factorial analysis showed no interaction between infestation and date (of infestation) at 5\% of probability. Also, there was no statistical difference on percentage of injury caused by leafminer between days 7 and 14 (Table 1). These results indicate that 7 days after infestation leafminer had completed most of its larval feeding. Leafminer development cycle is positively correlated with temperature from egg to pupa requiring about 10 days and pupation averaging 9 days at temperatures of $25^{\circ} \mathrm{C}$ (PARRELLA, 1987; NAKANO, 1993). At temperatures above $35^{\circ} \mathrm{C}$, larvae suffer high

Table 1 - Factorial analysis results $3 \times 2$ ( 3 treatments x 2 days of evaluation) for photosynthesis capacity using $\%$ of injury as co-variable and means $( \pm$ SE) of injury (\%) at 7 and 14 days after infestation.

\begin{tabular}{|c|c|c|c|c|}
\hline \multirow{2}{*}{ Effect } & \multicolumn{2}{|c|}{ Ancova } & \multicolumn{2}{|c|}{ Mined leaf area (\%) } \\
\hline & $\mathrm{F}$ & $\operatorname{Pr}>F$ & 7 days after infestation & 14 days after infestation \\
\hline Infestation & 2,70 & 0,084 & - & - \\
\hline day & 18,03 & 0,0002 & - & - \\
\hline Infestation*day & 0,01 & 0,99 & - & - \\
\hline block & 0,93 & 0,497 & - & - \\
\hline Injury & 0,06 & 0,815 & $8.37 \pm 1.78 \mathrm{a}$ & $12.38 \pm 1.78 \mathrm{a}$ \\
\hline
\end{tabular}

Means followed by the same letter are not statistically different according to Student $\mathrm{t}-$ test $(\mathrm{P}>0.05)$.

Ciência Rural, v.37, n.6, nov-dez, 2007. 
mortality and field temperatures may have prevented additional larval feeding in some cages.

Photosynthetic rates did not differ between infested leaflets and caged controls (Figure 1a), showing that for the level of infestation used in the experiment, leafminer injury did not alter photosynthesis of remaining tissue (uninjured tissue) of potato leaves. This finding contrasts reports that Liriomyza spp. injury reduced photosynthesis in celery (TRUMBLE et al., 1985), in tomato (JOHNSON et al., 1983), in lima beans (MARTENS \& TRUMBLE 1987), and in Chrysanthemum (PARRELLA et al., 1985). Several factors may explain the differences from our findings. It has been shown that potato is, in general, able to withstand high levels of defoliation without yield reduction, especially after blooming (SHIELDS \& WYMAN, 1984). For other crops, infestation levels were generally higher than those observed in our study. MORRISON \& REEKIE (1995) showed that degree of wounding often influences whether or not injury to the leaf itself impairs photosynthesis. For the level of injury observed in this trial, leafminer injury caused

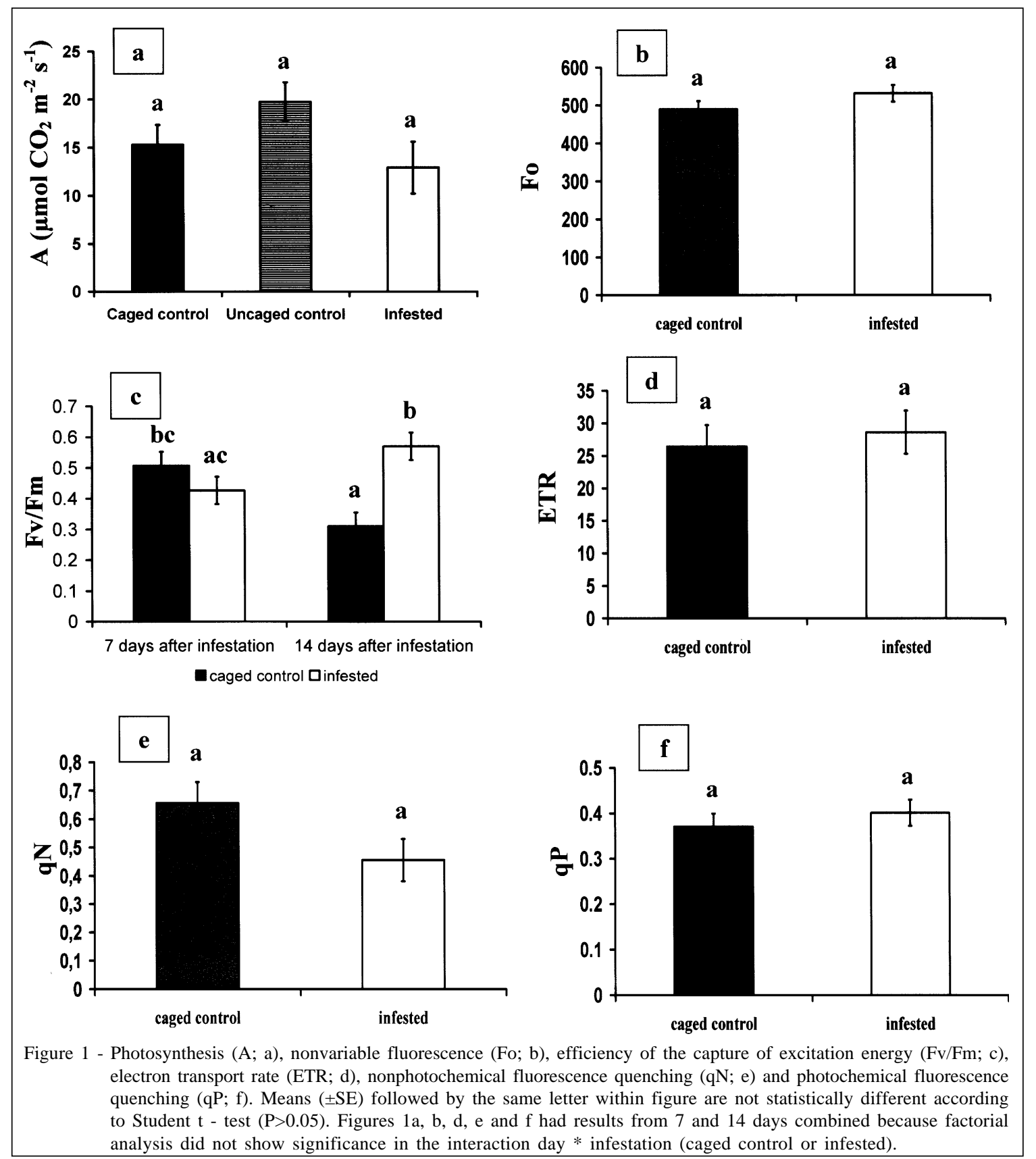

Ciência Rural, v.37, n.6, nov-dez, 2007. 
only photosynthetic leaf area reduction. This observation is important because lack of photosynthetic injury allows grouping of leafminer with the leaf-mass consumer injury guilds as proposed by PETERSON (2001). If leafminers, even at higher infestation levels, do not reduce photosynthesis of remaining leaf tissue, it may be further possible to create multiple species economic thresholds based on remaining leaf area.

Beyond the importance of establishing photosynthetic response of plants to biotic stress, increasingly attention has been focused on aspects of photoeclectron transport (MACEDO et al., 2003). Fluorescence readings indicate the function of light harvesting and photoelectron transport, representing an important tool on evaluating plant stress. Our examination of leaf fluorescence in leafminer-injured potato leaflets provides better insights on the physiological response of potato plants to leafminer injury. MACEDO et al. (2003), found an increase in nonvariable fluorescence (Fo) to indicate that light energy is being lost rather than passed through the phoelectron transport chain. Our results do not show any difference between Fo values of infested and caged control leaflets (Figure 1b). This indicates that the amount of light absorbed is being successfully transported through the phoelectron chain.

A second measure, the Fv/Fm ratio indicates how much light energy captured is being used by the reaction center and propagated through the photoelectron transport chain. We found that $\boldsymbol{L}$. trifolii injury significantly affected Fv/Fm ratio. There was a significant increase in the mean Fv/Fm ratio $0.427 \pm 0.045$ (7 days after infestation) to $0.5707 \pm 0.045$ (14 days after infestation) on infested leaflets $(\mathrm{P}<0.05)$. On day 14 after infestation, the $\mathrm{Fv} / \mathrm{Fm}$ ratio of infested leaflets $(0.5707 \pm 0.045)$ also differed from caged control leaflets $(0.3102 \pm 0.045)(\mathrm{p}<0.01)$ (Figure 1c). Chlorophyll fluorescence data was taken from 14:00 to 15:00 hours what probably led to a general low value for Fv/Fm. However, as we do have the controls and the insect injury is based on treatment comparison, our findings are still very important in order to clarify leafminer photosynthetic impairment. According to our results, leafminer injury affects the antennal chlorophyll complexes, causing the light to be reflected rather than absorbed. This observation indicates that even though no photosynthetic reduction was observed, remaining tissue of infested leaflets was stressed. The lack of photosynthetic reduction found in this study may be explained by the relatively short period of time that injury was present. Periods longer than 14 days might cause a reduction on photosynthesis and may explain observed early leaf senescence. Furthermore, the difference between injured leaves and control found 14 days after infestation on Fv/Fm is more likely a further decrease of $\mathrm{Fv} / \mathrm{Fm}$ value on control rather than any change due to infestation, since infestation level did not increase in intensity.

Another parameter to be evaluated when assessing photochemical efficiency is the electron transport chain (ETR). The ETR represents the apparent photosynthetic electron transport rate in $\mu \mathrm{mol}$ electrons $\mathrm{m}^{-2} \mathrm{~s}^{-1}$ (MACEDO et al., 2003). Our data show that ETR values for the test plants were not affected by leafminer injury (Figure 1d). Nonphotochemical fluorescence ( $\mathrm{qN}$ ) and photochemical fluorescence (qP) quenching coefficients provide information about the thylakoid membrane that are important to the proper functioning of the xanthophyll cycle. Our data indicate no difference between $\mathrm{qN}$ and $\mathrm{qP}$ values between infested and caged control leaflets (Figures 1e and 1f). Thus, the level of leafminer injury obtained in this study did not impact the protective xanthophyl cycle.

Overall, our results indicate that leafminer injury of up to $13 \%$ of total leaf area do not impact photosynthetic rates of remaining leaf tissue while fluorescence results suggest that light absorbance may be a limiting factor for photosynthetic efficiency in leafminer-injured plants. Also, it is important to point out that plant responses to insect injury might vary at different levels of biological organization (PETERSON \& HIGLEY, 1993). Thus, when photosynthesis is not altered by insect injury at the individual organ (leaf), it might be altered at the plant level (PETERSON \& HIGLEY, 1993). For example, induced leafmining has been shown to induce early leaf abscission on American holly, (Ilex opca), an ornamental plant (KAHN \& CORNELL, 1989) and transmit viruses on celery and squash (ZITTER \& TSAI, 1977). These injuries do not affect the injured plant organ exclusively, but affect the entire plant. They can directly or indirectly reduce canopy photosynthetic rates. Consequently, additional research on the mechanisms underlying leafminer injury on potato plants is still needed.

Samples, taken before the first application of abamectin, show a general increase in the number of live larvae per 40 leaves (Figure 2a). The number of parasitized leafminer larvae also increased and generally showed one to two day lag response (Figure 2b). After the first treatment of abamectin, the number of larvae decreased rapidly in the southwest quadrant of the field (abamectin 583mL ha-1). While there was no sampling in the southeast quadrant before the abamectin treatment, scouting data suggest that it takes five to seven days for the abamectin to reduce larval population numbers. Samples were taken 3 days after 


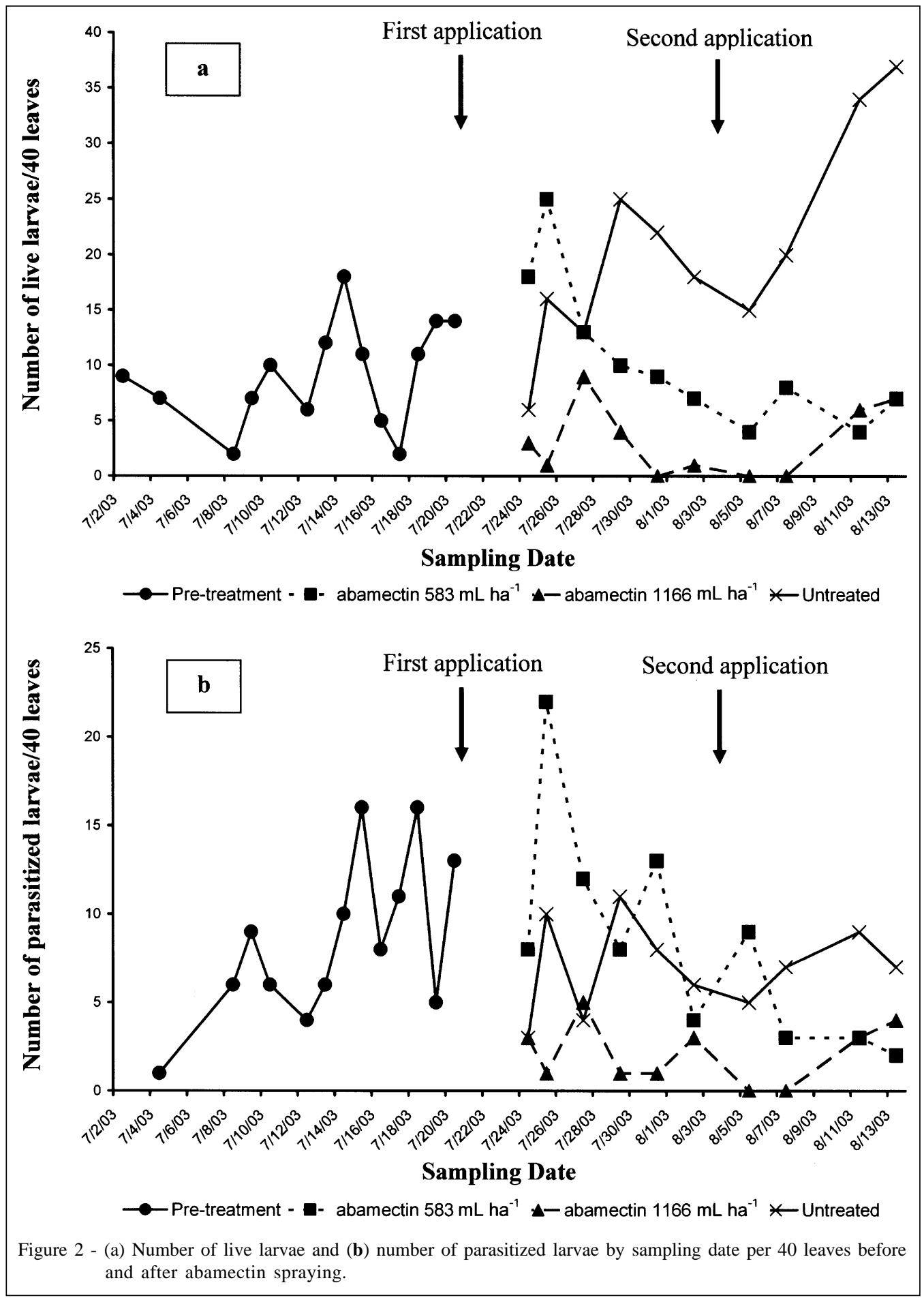

the first treatment and, while populations were never as high as the north or southwest quadrants, the southeast quadrant (abamectin $1166 \mathrm{~mL} \mathrm{ha}^{-1}$ ) showed a substantial decrease in live larvae. The untreated north half of the field exhibited a rapid growth in the leafminer larvae population (Figure 2a).
Leafminers are naturally parasitized by a number of wasps belonging to the families Braconidae, Eulophidae, and Pteromalidae which provide natural control. We recorded the number of parasitized larvae, later identified as the family Eulophidae, to determine if natural enemies would control the infestation. We 
found that the number of parasitized larvae were always lower than the numbers of live larvae in all study areas and in the north half of the field the number of parasitized larvae plateaued at about seven parasitized larvae per 40-leaf sample. However, the number of live larvae sampled per 40-leaf sample increased almost exponentially in the latter portion of the observation period (Figures 2a and b). These data show that parasitic wasps alone cannot effectively control leafminer larvae at this level of infestation.

The numbers of live leafminer larvae were successfully managed in the southwest (abamectin $583 \mathrm{~mL} \mathrm{ha}^{-1}$ ) and the southeast (abamectin $1166 \mathrm{~mL} \mathrm{ha}^{-1}$ ) quadrants, however the number of parasitized larvae also decreased in both quadrants (Figures 2a and b). While the higher application rate of abamectin immediately reduced the number of live larvae compared to the lower application rate of abamectin, by the end of the season both treatment areas had similar numbers of live larvae per sample (Figure 2a). These data suggest that the $583 \mathrm{~mL} \mathrm{ha}^{-1}$ application of abamectin coupled with the added benefit of parasitism by parasitic wasps will be the most appropriate management strategy.

The findings presented in this study are helpful, but there are several drawbacks to the study. Because this study was conducted under field conditions the southwest, southeast, and north study areas did not have the same initial leafminer populations. The infestation began in the southwest quadrant and moved into the north half and the southeast quadrants of the field later in the season. The canopy in the southwest quadrant of the field declined dramatically before the canopies of the north half and the southeast quadrant of the field. It is unclear if this premature leaf drop was due to the extended period of time that the leafminer population occupied the southwest quadrant of the field or if there was another factor that may have been responsible. Lastly, there was no true control in this study. While the data show that there was no effect of insecticide drift from the south half of the field to the north, the possibility cannot be ignored because of the prevailing southerly winds of summer in south-central Nebraska.

\section{CONCLUSIONS}

Leafminers impacts potato plants similarly to defoliators so Economic Injury Levels developed for Defoliators might be also used for leafminers. Among the chemical options available, abamectin is a good control option to be applied on leafminer outbreaks with low impact on biological control.

\section{ACKNOWLEDGMENTS}

We acknowledge M. P. Parrella from the Department of Entomology, University of California, Riverside for sending us the pupae. CSS Farms allowed access to the fields. The grant support for A. F. Bueno was provided by Fulbright Commission's Council for International Exchange of Scholars and CAPES, Brazil. Helpful comments on experimental design were provided by Leon Higley, Tulio Macedo, and Paul Nabity.

\section{REFERENCES}

EWELL, P.T. et al. Farmer management of potato insects in Peru. Lima: International Potato Center, 1990. 87p.

HIGLEY, L.G. Yield loss and pest management. In: PETERSON, R.K.D.; HIGLEY, L.G.. Biotic stress and yield loss. Boca Raton; CRC, 2001. Chap.2, p.13-22.

HILJE, L. et al. Validacion de umbrales de accion para el combate de Liriomyza huidobrensis en parcelas de papa en Cartago, Costa Rica. In:____. Taller de actualizacion sobre Liriomyza huidobrensis y perspectivas para futures investigaciones. Cartago: Costa Rica, MAG/CATIE, 1993. p.71-74.

JOHNSON, M.W. et al. Reduction of tomato leaflet photosynthetic rates by mining activity of Liriomyza sativae (Diptera: Agromyzidae). Journal of Economic Entomology, v. 76, p.1061-1063, 1983.

KAHN, D.M.; CORNELL, H.V. Leafminers, early leaf abscission, and parasitoids: a tritrophic interaction. Ecology, v.70, p.1219-1226, 1989.

MACEDO, T.B. et. al. Photosynthetic responses of soybean to soybean aphid (Homoptera: Aphididae) injury. Journal of Economic Entomology, v.96, p.188-193, 2003.

MARTENS, B.; TRUMBLE, J.T. Structural and photosynthetic compensation for leafminer (Diptera: Agromyzidae) injury in lima beans. Environmental Entomology, v.16, p.374-378, 1987.

MORRISON, K.D.; REEKIE, E.G. Pattern of defoliation and its effect on photosynthetic capacity in Oenothera biennis. Journal of Ecology, v.83, p.759-767, 1995.

NAKANO, O. Mosca-minadora: o caminho da prevenção. Sinal Verde, v.6, p.8-9, 1993.

PARRELlA, M.P. Biology of Liriomyza. Annuals Review of Entomology, v.32, p.201-224, 1987

PARRELLA, M.P. et. al. Effect of leaf mining and leaf stippling of Liriomyza spp. on photosynthetic rates of Chrysanthemum. Annuals Entomology Society American, v.78, p.90-93, 1985.

PETERSON, R.K.D. Photosynthesis, yield loss, and injury guilds. In: PETERSON, R.K.D.; HIGLEY, L.G. Biotic stress and yield loss. Boca Raton: CRC, 2001. Chap.6, p.83-98.

PETERSON, R.K.D.; HIGLEY, L.M. Arthropod injury and plant gas exchange: Current understandings and approaches for 
synthesis. Trends in Agricultural Sciences, v.1, p.93-100, 1993.

SAS Intitute. SAS user's guide: statistics, version $8 \mathbf{e}$. Cary, NC, 2001. 108p.

SHIELDS, E.J.; WYMAN, J.A. Effect of defoliation at specific growth stage on potato yield. Journal of Economic Entomology, v.77, p.1194-1199, 1984

SOUZA, J.C. Mosca minadora: evitando prejuízos. Sinal Verde, v.6, p.10-11, 1993.
SOUZA, J.C.; REIS, P.R. O minador-das-folhas da batata. Informe Agropecuário, v.20, p.77-84, 1999.

SPENCER, K.A. Agromyzidae (Diptera) of economic importance. Series Entomológica, v.9, p.1-418, 1973.

TRUMBLE, J.T. et. al. Analysis of physiological, growth, and yield responses of celery to Liriomyza trifolii. Entomology Experimentalis et Applicatta, v.38, p.15-21, 1985.

ZITTER, T.A.; TSAI, J.H. Transmission of three potyviruses by the leafminer, Liriomyza sativae (Diptera: Agromyzidae). Plant Disease Report, v.61, p.1025-1029, 1977. 